$\begin{array}{lll}\text { JST 8 (2) (2019) } & \text { JURNAL SENI TARI } \\ \text { Terakreditasi SINTA 5 } & \text { http://iournal.unnes.ac.id/siu/index.php/ist }\end{array}$

\title{
Pertunjukan Wayang Orang Njajah Desa Milang Kori RRI Surakarta Lakon Gatotkaca Gandrung
}

\author{
Dwi Yullastuti ${ }^{1}$, Hasan Bisri ${ }^{2}$ \\ Jurusan Pendidikan Sendratasik, Fakultas Bahasa dan Seni Universitas Negeri Semarang
}

\begin{tabular}{l}
\hline Info Artikel \\
\hline Sejarah Artikel \\
Diterima : \\
22 Oktober 2019 \\
Disetujui : \\
10 November 2019 \\
Dipublikasikan : \\
26 November 2019
\end{tabular}

Keywords:

Concept of Performance, Wayang Orang, Njajah Desa Milang Kori,

Performance Element

\begin{abstract}
Abstrak
Konsep Njajah Desa Milang Kori dalam pertunjukan Wayang Orang RRI Surakarta yaitu melakukan pertunjukan secara berkeliling desa atau kota. Tujuan penelitian ini adalah untuk menjelaskan konsep, mendeskripsikan serta mengkaji unsur pertunjukan Wayang Orang dalam Njajah Desa Milang Kori di RRI Surakarta. Metode yang digunakan adalah metode penelitian kualitatif dengan pendekatan dramaturgi. Data diperoleh melalui observasi, wawancara dan dokumentasi yang diabsahkan menggunakan triangulasi, kemudian dianalisis dengan proses pengumpulan data, reduksi data, penyajian data dan penarikan simpulan. Hasil penelitian menunjukkan konsep pertunjukan Wayang Orang dalam Njajah Desa Milang Kori adalah menggelar pertunjukan secara berpindah-pindah tempat, berkeliling desa atau kota. Pertunjukan Wayang Orang keliling desa telah terlaksana sebanyak 8 (delapan) kali, dengan judul dan tempat pertunjukan yang berbeda-beda sejak tahun 2012 hingga Januari 2019. Konsep garap pertunjukan Wayang Orang menggunakan konsep konvensional, yaitu sama dengan pertunjukan Wayang Orang pada umumnya. Masyarakat dapat menyaksikan pertunjukan secara gratis, meskipun demikian tetap mengutamakan sajian yang berkualitas yaitu lengkap dengan unsur pertunjukannya. Adapun unsur pertunjukannya sama dengan pertunjukan Wayang Orang konvensional pada umumnya, namun ada beberapa perbedaan yang terjadi secara kondisional menyesuaikan dengan lokasi dan lingkungannya.
\end{abstract}

\begin{abstract}
The concept of Njajah Desa Milang Kori in the Wayang Orang RRI Surakarta performance is to perform a tour around the village or city. The purpose of this study is to explain the concept of the show and describe and examine the elements of the Wayang Orang in Njajah Milang Kori Village performance at RRI Surakarta. The method used is a qualitative research method with the dramaturgy approach. Data obtained through observation, interviews and documentation which is validated using triangulation, then analyzed by the process of data collection, data reduction, data presentation and drawing conclusions. The results showed that the concept of the Wayang Orang in Njajah Milang Kori Village was a show touring the village or moving from one village to another. Wayang Orang performance has done around the village and can be proven by the implementation of activities eight times, with different titles and venues from 2012 to January 2019. The concept of working on the Wayang Orang performance uses a conventional concept, which is the same as the Wayang Orang performance in general. People can watch the performance for free, even though it still prioritizes a quality dish that is complete with elements of the performance. The elements of performance are same with conventional Wayang Orang performances in general, but there are some differences that occur conditionally depending on the location and environment.
\end{abstract}

(C) 2019 Universitas Negeri Semarang

Alamat korespondensi: ISSN 2503-2585

Masukkan alamat lengkap

Email : 1.dwivullastuti0@gmail.com

2. hasanbisriunnes@mail.unnes.ac.id 


\section{PENDAHULUAN}

RRI Surakarta adalah satusatunya radio yang memiliki tonil Wayang Orang se-Indonesia. Wayang Orang tersebut disajikan dalam dua jenis yaitu tonil Wayang Orang yang penyajiannya secara audiovisual atau sering disebut Wayang Orang "deprokan" dan panggung Wayang Orang. Wayang Orang deprokan, deprokan berasal dari kata deprok atau duduk lesehan yang berarti para pemain wayang tersebut hanya berdialog sambil duduk mengelilingi pengeras suara di studio rekaman siaran. Penyajian yang kedua adalah panggung Wayang Orang, RRI Surakarta memiliki panggung untuk pementasan Wayang Orang. Pemainnya adalah pegawai RRI Surakarta. Pementasan dilakukan menggunakan busana dan riasan lengkap serta unsur pertunjukan lain layaknya pementasan Wayang Orang pada umumnya.

Radio berbasis budaya ini memiliki kegiatan unggulan diluar kegiatan rutin, yaitu Njajah Desa Milang Kori (NDMK). Kegiatan unggulan ini berlangsung sejak tahun 2012 dan telah melakukan pertunjukan sebanyak delapan kali dengan lakon yang berbeda-beda hingga Januari 2019. Njajah Desa Milang Kori dalam bahasa gaul disebut "road show" atau pentas keliling. Dalam istilah bahasa Jawa, Njajah artinya Menjelajah, Desa atau Kota, Milang artinya Membilang atau Menghitung dan Kori artinya Pintu. Secara luas memiliki makna menjelajah dari satu tempat ke tempat lain. Dengan demikian, tekanan makna istilah NDMK bukan hanya kata 'desa' tetapi juga dimanapun tempat, termasuk juga kota.

Pentas Njajah Desa Milang Kori adalah bagian dari upaya nyata mendekatkan wayang pada publik. Publik disini memiliki makna masyarakat yang lebih luas, meliputi kewilayahan, usia, tingkat pendidikan, kemampuan ekonomi, profesi, status sosial dan sebagainya. Jadi diharapkan semua masyarakat merasa memiliki dan mencintai wayang. Kegiatan ini juga merupakan salah satu bentuk perluasan kreasi seniman dan sekaligus untuk menggenapi rasa rindu masyarakat penikmat wayang akan pergelaran Wayang Orang yang sesungguhnya.
Pentas Wayang Orang Njajah Desa Milang Kori mempunyai beberapa fenomena menarik untuk dikaji. Pertama karena kegiatan ini sebagai pentas seni yang nyata berpihak pada publik atau masyarakat luas. Kedua, berkomitmen untuk menyajikan garapan yang tetap menjaga kualitas, garapan bukan merupakan penyederhanaan dari Wayang Orang namun sebuah format lengkap yang diupayakan setara kualitasnya dengan Wayang Orang yang diselenggarakan di gedung-gedung pertunjukan. Dengan kata lain pada keunikan yang kedua adalah pertunjukan Wayang Orang yang dilakukan secara outdoor atau di luar gedung pertunjukkan. Sedangkan dalam pementasan Wayang Orang yang dilakukan di dalam gedung biasanya menggunakan tata panggung yang sudah lengkap dan tertata permanen, namun dalam kegiatan Njajah Desa Milang Kori pemain Wayang Orang maupun crew panggung harus dapat menyesuaikan dengan tempat yang seadanya dan konsekuensi cuaca yang tidak dapat ditebak. Ketiga, pertunjukan dilakukan secara berkeliling desa berpindah-pindah dari satu desa ke desa lain. Kegiatan tersebut hanya diselenggarakan oleh Wayang Orang RRI Surakarta.

Penelitian terkait Konsep Pertunjukan Wayang Orang dalam Njajah Desa Milang Kori di RRI Surakarta belum peneliti jumpai. Jurnal Dwi Retno Sulanjari tahun 2016 berjudul Regenerasi Wayang Orang Sriwedari dengan hasil penelitian berupa regenerasi Wayang Orang yang ada di Sriwedari. Kesamaan dengan penelitian ini yaitu membahas mengenai Wayang Orang dan unsur-unsur yang ada di dalamnya, sedangkan perbedaannya yaitu pada kajian yang dibahas yaitu regenerasi pemain Wayang Orang dengan konsep pertunjukan berkeliling desa. Relevansi dengan penelitian ini yaitu memberikan wawasan mengenai pengertian Wayang Orang dan unsur-unsur pertunjukannya.

Jurnal terkait selanjutnya yaitu Jurnal Maharsidewi Kusharyani dkk tahun 2016 berjudul Eksistensi dan Perlindungan Wayang Orang Sriwedari Surakarta di Tinjau dari Aspek Hukum Hak Cipta dengan hasil penelitian berupa eksistensi 
serta perlindungan ditinjau dari hak cipta untuk mengetahui peran dan upaya yang dilakukan Pemerintah Kota Surakarta untuk melindungi dan melestarikan Wayang Orang Sriwedari Surakarta. Penelitian memiliki kesamaan mengenai pembahasan Wayang Orang yang hidup dan berkembang di Kota Surakarta serta unsur-unsur pertunjukan Wayang Orang. Perbedaan terletak pada objek kajian penelitian yaitu Wayang Orang Sriwedari dan eksistensinya dengan Konsep Pertunjukan Wayang Orang RRI Surakarta. Relevansi dengan penelitian ini yaitu memberikan informasi mengenai Wayang Orang dan unsur-unsurnya.

Tulisan ini membedah mengenai konsep pertunjukan Wayang Orang Njajah Desa Milang Kori yang mengandung unsur pendukung dalam Wayang Orang meliputi dalang, tema, alur cerita, adegan, dialog, seni tari, tata rias dan busana, properti, iringan dan tempat pertunjukan

\section{METODE}

Penelitian ini menggunakan metode penelitian kualitatif. Menurut Sugiyono (2015: 14-15) metode penelitian kualitatif adalah metode penelitian yang berlandaskan pada filsafat post positivisme (paradigma yang memandang realitas sosial sebagai sesuatu yang utuh, kompleks, dinamis, penuh makna, hubungan gejala bersifat interaktif). Metode ini digunakan mengingat objek yang diteliti merupakan suatu realita yang utuh dan komplek sehingga memenuhi filsafat postpositivisme berdasarkan pendapat Sugiyono.

Penelitian ini menggunakan pendekatan dramaturgi menurut Harymawan. Menurut Harymawan (1986: 1) dramaturgi adalah ajaran tentang masalah hokum dan konvensi drama, keahlian dan teknik penyusunan karya dramatik, sebuah teori yang mempelajari seluk beluk cerita atau naskah scenario yang di dalamnya terdapat studi struktur dramatik, plot, tema, penokohan dan setting peristiwa. Unsur-unsur dalam teori dramaturgi memiliki unsur yang sama dengan pertunjukan Wayang Orang, sehingga pendekatan dramaturgi adalah pendekatan yang tepat untuk membedah pertunjukan Wayang Orang.
Data penelitian ini didapatkan menggunakan metode observasi tidak terstruktur, wawancara langsung dengan jenis wawancara semi terstruktur dan dokumentasi. Observasi dilakukan pada tanggal 19 Desember 2019 di RRI Surakarta dengan tujuan perkenalan dan memohon izin penelitian dan pada 26 Januari 2019 di Boyolali menyaksikan pertunjukan. Wawancara dilakukan sebanyak delapan kali di bulan Juli 2019 dengan Ali Marsudi selaku pencetus dan sutradara Wayang Orang Njajah Desa Milang Kori dan beberapa pemain Wayang Orang RRI Surakarta yang terlibat dalam Njajah Desa Milang Kori seperti Edi Sulistiono sebagai dalang, Aris Murtono sebagai koordinator Wayang Orang, Wahyu Sapto sebagai koreografer dan lainlain. Data yang dikumpulkan berupa data foto tentang RRI dan foto tentang pertunjukan Njajah Desa Milang Kori, berupa data video dan data catatan-catatan admisnistratif sebagai dokumentasi penelitian.

Data yang telah dikumpulkan kemudian diabsahkan menggunakan pengujian kredibilitas dengan melakukan observasi dan wawancara berulang kali, triangulasi sumber dan waktu, meningkatkan ketelitian dan menggunakan bahan referensi.

Langkah selanjutnya setelah mendapatkan data yang sah peneliti melakukan analisis data dengan reduksi data, menyajikan data dan menarik simpulan. Berikut merupakan langkahlangkah yang dilakukan peneliti dalam menganalisis data.

Pertama yaitu Reduksi data, peneliti melakukan transkip rekaman wawancara. Kemudian mengelompokkan foto berdasarkan waktu pengambilan foto dan dokumentasi lainnya. Kedua yaitu penyajian data, peneliti melakukan interpretasi data yang diperoleh dari berbagai sumber, kemudian disajikan dalam bentuk paragraph deskriptif yaitu penuangan informasi lebih banyak menggunakan huruf dan bukan angka. Peyajian data telah disesuaikan menggunakan urutan yang sistematis sehingga dapat dipahami dengan baik dan jelas. Ketiga yaitu penarikan simpulan, peneliti membandingkan hasil yang telah 
diketik dalam bentuk paragraf deskriptif setelah melakukan wawancara dengan narasumber. Beberapa pernyataan mungkin terjadi kesamaan dan perbedaan pendapat, kemudian peneliti menanyakan kembali atau klarifikasi data dengan pihak terkait tanpa menyebutkan narasumber awal guna menghindari kesalahpahaman.

\section{HASIL DAN PEMBAHASAN}

\section{Konsep Pertunjukan Wayang Orang RRI Surakarta}

Sebagai pengantar sebelum menjelaskan mengenai konsep pertunjukan Wayang Orang Njajah Desa Milang Kori, peneliti membahas mengenai konsep pertunjukan Wayang Orang RRI Surakarta sebagai gambaran konsep pertunjukan yang dilakukan secara konvensional menetap di gedung pertunjukan.

Pembahasan konsep pertunjukan Wayang Orang di RRI Surakarta dapat dianalisis menggunakan konsep Soedjadi (2000 : 14) bahwa konsep adalah ide abstrak yang dapat digunakan untuk menggolongkan atau mengklasifikasikan sekumpulan objek yang biasanya dinyatakan dengan suatu istilah atau rangkaian kata. Pemaknaan konsep kemudian dilengkapi dengan pendapat Singarimbun dan Effendi (1989: 34) adalah

"Abstraksi mengenai suatu fenomena yang dirumuskan atas dasar generalisasi dari sejumlah karakteristik kejadian, keadaan, kelompok atau individu tertentu".

Dengan kata lain yaitu sebagai istilah dan definisi yang digunakan untuk menggambarkan secara abstrak suatu kejadian, keadaan, kelompok atau individu yang menjadi pusat perhatian ilmu sosial. Konsep terdiri dari dua jenis menurut Singarimbun dan Effendi, yang pertama konsep-konsep yang jelas hubungannya dengan fakta atau realitas yang mereka wakili atau konkret, dan kedua ialah konsep abstrak atau tidak jelas hubungannya dengan fakta atau realitas. Contoh konsep yang pertama adalah kursi yaitu istilah yang dapat diamati wujudnya, sedangkan contoh konsep yang kedua adalah hubungan sosial yaitu istilah yang abstrak dan tidak berwujud.Konsep diciptakan dengan menggolongkan dan mengelompokkan objek-objek tertentu yang mempunyai ciri-ciri yang sama.

Bagian Kesenian RRI Surakarta memiliki kegiatan rutin yaitu tonil Wayang Orang, tonil Ketoprak, pentas Panggung Wayang Orang, pentas Panggung Ketoprak, siaran-rekaman karawitan dan sandiwara radio yang semuanya terselenggara di dalam ruang lingkup RRI Surakarta. Pertunjukan Panggung Wayang Orang RRI Surakarta mempersembahkan pertunjukan Wayang Orang yang berbicara tentang budaya lokal yaitu budaya Indonesia. Wayang Orang RRI Surakarta merupakan pertunjukan Wayang Orang yang bukan hanya memberikan tontonan, tapi juga memberikan tuntunan baik melalui dialog dalam pertunjukan.

Pertunjukan Wayang Orang RRI Surakarta ditampilkan secara rutin setiap satu bulan sekali pada hari Selasa minggu kedua. Sajian yang dibawakan selalu berganti-ganti sesuai dengan kehendak sutradara pembuat lakon. Tempat pertunjukan di gedung auditorium yang berada di RRI Surakarta yaitu auditorium Sarsito Mangoenkoesoemo. Prasarana gedung telah dilengkapi panggung khusus untuk pertunjukan, terdapat fasilitas alat perekam, panggung, tempat gamelan, tempat duduk penonton, ruang rias, sound sistem dan lighting. Panggung pertunjukan termasuk panggung konvensional seperti yang terdapat pada panggung petunjukan pada umumnya, jenis panggung termasuk jenis proscenium yang memiliki ciri-ciri ketinggian, berjarak antara pemain dengan penonton.

Persiapan sebelum melaksanakan pertunjukan rutin Wayang Orang di RRI Surakarta yaitu dengan melakukan latihan. Jadwal latihan diatus oleh Aris Murtono selaku koordinator Wayang Orang. Latihan dilakukan bersama semua pemain baik sutradara, penata tari, dalang, dan kelompok karawitan satu hari sebelum pertunjukan dilaksanakan. Pertunjukan Wayang Orang biasanya dimulai pukul 20.00 WIB. Teknis dan persiapan pertunjukan berlangsung cepat karena semua alat sudah tertata pada tempatnya. Teknisi telah memegang kendali tugasnya masing-masing dan ahli dibidangnya. 
Pemain Wayang Orang adalah pegawai RRI Surakarta yang bekerja dibagian siaran kesenian. Pertunjukan rutin Wayang Orang RRI Surakarta selain diperankan oleh pemain dari RRI, juga melibatkan seniman dari luar. Beberapa pertunjukan merangkul kerjasama dengan seniman dari luar misalkan dari mahasiswa ISI Surakarta, siswa serta guru dari SMK N 8 Surakarta dan senimanseniman lain. Salah satu alasan merangkul kerjasama dengan seniman dari luar adalah kurangnya personil dari dalam, karena sudah banyak yang pensiun sedangkan tuntutan peran harus selalu segar dihadapan penonton. Oleh karena itu perlu dukungan seniman dari luar. Meskipun demikian, pemain Wayang Orang di RRI Surakarta tetap berusaha eksis tampil dihadapan masyarakat dengan tetap mempertahankan kualitas yang baik.

Berdasarkan penjelasan dapat dijelaskan bahwa konsep pertunjukan Wayang Orang RRI Surakarta menggunakan konsep abstrak yaitu konvensional. Konsep konvensional dapat dilihat dari segi tempat pertunjukan yang menetap, pertunjukan menggunakan unsur pendukung lengkap berupa dalang, tema, alur cerita, adegan, tata busana, tata rias, property dan dialog yang sama dengan pertunjukna konvnesional pada umumnya.

Konsep pertunjukan dilakukan di dalam gedung pertunjukan sehingga masyarakat yang datang mengunjungi tempat pertunjukan. Masyarakat dapat menyaksikan pertunjukan secara gratis, namun di lobi depan disiapkan kotak untuk tempat dana yang bersifat sukarela. Konsep tersebut dapat dijelaskan bahwa penonton yang mendatangi pertunjukan bukan pertunjukan yang mendatangi penonton. Meskipun demikian, masyarakat sekitar memiliki antusias dan respon yang baik.

\section{Konsep Pertunjukan Wayang Orang Njajah Desa Milang Kori}

Pertunjukan Wayang Orang

Njajah Desa Milang Kori dalam istilah Bahasa Jawa memiliki arti Njajah Desa yaitu Menjelajah, Desa yaitu Desa atau Kota, Milang yaitu Membilang atau Menghitung, dan Kori yaitu Pintu. Secara luas memiliki makna menjelajah dari satu tempat ke tempat yang lain. Dengan demikian, tekanan makna istilah NDMK bukan hanya kata 'desa' namun juga dimanapun tempat, termasuk juga kota. Njajah Desa Milang Kori atau dapat disingkat NDMK, dalam bahasa gaul disebut "road show" atau pentas keliling.

Kegiatan yang dilakukan yaitu melakukan pertunjukan berpindah tempat dari satu desa ke desa lain, menyambangi kota-kota kecil bahkan di seluruh Indonesia. Pentas NDMK adalah bagian dari upaya nyata mendekatkan wayang pada publik yang memiliki makna masyarakat yang lebih luas, yaitu meliputi kewilayahan, usia, tingkat pendidikan, kemampuan ekonomi, profesi, status sosial dan sebagainya. Sehingga diharapkan semua merasa memiliki dan mencintai Wayang Orang. Kegiatan tersebut dapat dijelaskan bahwa Wayang Orang Njajah Desa Milang Kori memiliki visi dan misi yaitu, visi adalah memasyarakatkan kembali Wayang Orang sampai ke pelosok desa, memberikan tontonan yang berisi tuntunan nilai-nilai kehidupan yang adiluhung dan tuntunan baik di dalamnya. Misi adalah menggelar pertunjukan berkeliling desa maupun kota.

Pertunjukan Wayang Orang dalam Njajah Desa Milang Kori telah melakukan pertunjukan sebanyak delapan kali dengan lakon dan tempat yang berbeda-beda, yaitu: (1) Burisrawa Ketlikung Wuyung di Kemuning (2) Abimanyu Wuyung, Gareng Gandrung di Pracimantoro (3) Wasi Jaladara (Alap-alapan Erawati) di Terminal Karangpandan (4) Wahyu Cakraningrat di Lapangan Desa Samiran, Boyolali (5) Arjuna Kembar di Prambanan (6) Begawan Kilat Buana di Terminal Jatipuro (7) Pandhu Dewanata di Ngargoyoso, Karangpandan (8) Gatotkaca Gandrung di Potronayan, Boyolali.

Penelitian mengambil contoh pertunjukan Gatotkaca Gandrung di Potronayan, Boyolali pada 26 Januari 2019 guna mempermudah menjelaskan bentuk pertunjukan berupa unsur-unsur pendukung Wayang Orang. Unsur pendukung dalam Wayang Orang meliputi dalang, tema, alur cerita, adegan, dialog, seni tari, tata rias dan busana, properti, iringan dan tempat pertunjukan. 


\section{Dalang}

Tokoh utama pemegang kendali sebuah pertunjukan wayang adalah seorang dalang. Menurut Claire Jolt (200:175) dalang adalah kekuatan sentral dari dunia wayang. Dalang merupakan tokoh yang tidak lepas dari sebuah pertunjukan wayang kulit dan Wayang Orang, begitupula dengan pertunjukan Wayang Orang dalam Njajah Desa Milang Kori. Berikut wawancara mengenai peran dalang dengan dalang Edi Sulistiono;

\begin{abstract}
"peranan dalang dalam Wayang Orang adalah sebagai narator, memperjelas cerita, mengkait-kaitkan adegan yang satu dengan adegan yang lain dan mempertajam drama. Jane ta dek, sandiwara Jawa kuwi kabeh nganggo dalang contohnya Langendrian, Pranaswara dengan cerita panji, Wayang Topeng juga pakai dalang mbak. Nah kalau Bahasa yang digunakan dalang itu bahasa pedalangan atau sastra pedalangan, genre yang khusus karena kesastraan wayang itu menggunakan berbagai macam undha ususking basa artine macam-macam bahasa antara lain yang digunakan disitu Bahasa Kawi, Sastra Jawa Tengahan, Basa Rinengga dan Basa Ngoko. Kemudian tugasnya mendukung iringan dengan sulukan, kumbangan, tembangan, dodokan dan keprakan. Lah dodokan dan keprakan dalang iku nuntun beksa penjoget, yen kleru le ndodok ya klewu le njoget. Kalau keprak itu memantapkan gerak, kayane sepele tapi sebenarnya tidak mbak". (wawancara 8 Agustus 2019)
\end{abstract}

Berdasarkan wawancara, dalang memiliki peran sebagai narator, memperjelas cerita, mengkait-kaitkan adegan yang satu dengan adegan yang lain dan mempertajam drama.

Bahasa yang digunakan yaitu "undha usuking basa" yang memiliki arti terdiri dari berbagai macam bahasa, antara lain Bahasa Jawa Kawi, Bahasa Jawa Tengahan, Bahasa Rinengga dan Bahasa Ngoko. Menurut Wikipedia Bahasa Jawa Kawi adalah salah satu jenis Bahasa yang pernah berkembang di Pulau Jawa pada zaman kerajaan Hindu-Budha nusantara dan dipakai dalam penulisan karya-karya sastra. Dalam tradisi Jawa, Bahasa Jawa Kawi juga disebut Bahasa Jawa Kuno. Meskipun demikian, Bahasa Jawa Kawi sendiri bukan Bahasa Jawa Kuno murni, karena telah mendapat pengaruh Bahasa sanskerta. Bahasa Jawa pertengahan muncul di Kerajaan Majapahit, mulai dari abad ke-13 sampai kira-kira abad ke-16. Kemudian sastra Jawa Tengahan diteruskan di Bali menjadi Sastra Jawa-Bali.

Bahasa Rinengga adalah Bahasa yang merangkai satu kata dengan kata lain sehingga menjadi sebuah Bahasa yang indah dan menarik hati, yang biasanya digunakan dalam pedalangan, sambutan pernikahan dan lainnya. Kemudian Bahasa Ngoko adalah salah sbahasa yang paling umum digunakan oleh kalangan orang Jawa. Pemakaiannya dihindari untuk berbicara dengan orang yang dihormati atau orang yang lebih tua.

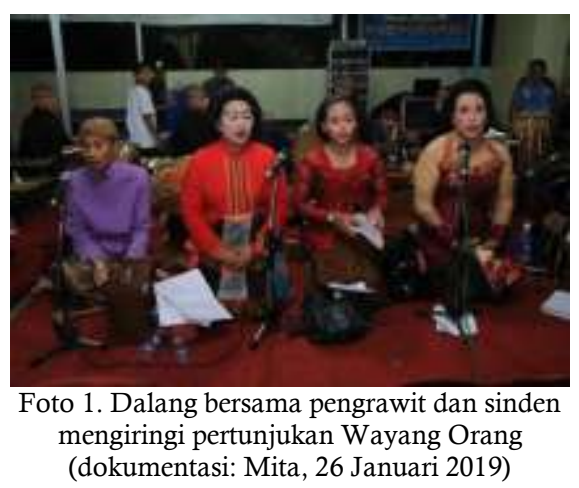

Dalang menggunakan busana Jawi Jangkep yaitu busana jawa lengkap meliputi jarik, beskap, dan blangkon.

\section{Tema}

Tema merupakan ide, gagasan, pandangan hidup pengarang yang melatarbelakangi ciptaan karya sastra, sudah cukup memberikan pengertian tema secara menyeluruh, Zainudin Fananie (2001:84). Satu ide tersebut sudah cukup memberikan pengertian tema secara menyeluruh pada suatu hasil karya seni.

Wayang Orang memiliki tema khusus yang dapat diklasifikasikan sebagai berikut menurut wawancara dengan Ali Marsudi; (1) tema pernikahan atau percintaan, sebagai contoh Gatotkaca Gandrung, Gatotkaca Krama, Arjuna Krama, 
dan lain sebagainya. (2) tema turunnya wahyu, sebagai contoh Wahyu Cakraningrat, Wahyu Purbasejati, dan lain sebagainya. (3) tema kelahiran, sebagai contoh Gatotkaca Lahir, Abimanyu Lahir, Wisanggeni Lahir, dan lain sebagainya. 4) tema kematian, sebagai contoh Gatotkaca Gugur, Pandu Gugur, Duryudana Gugur, dan lain sebagainya. 5) tema peperangan, sebagai contoh Perang Baratayuda, Perang Kembang, Perang Pamuksa, dan lain sebagainya.

Berdasarkan uraian mengenai tema, pertunjukan Gatotkaca Gandrung menggunakan tema pernikahan atau perkawinan, di dalam tema pernikahan atau perkawinan tersebut didalamnya mengandung tema percintaan, karena dalam sebuah pernikahan pasti membahas mengenai cinta. Pertunjukan Wayang Orang Gatotkaca Gandrung menceritakan tentang pernikahan Gatotkaca dan Pregiwa yang sempat dibatalkan, kemudian karena kesungguhan cinta Gatotkaca dan Pregiwa sehingga mereka berjuang dan akhirnya dapat menikah.

\section{Alur Cerita}

Alur merupakan runtutan dari beberapa peristiwa yang dikelompokan menjadi satu dan saling berhubungan kemudian terlihatlah sebuah susunan peristiwa yang berkualitas (terdapat sebabakibat). Sebuah peristiwa akan menjadi penyebab atau akibat dari peristiwa yang lain atau sekelompok peristiwa lain, Hasanudin (1996:89). Alur cerita dalam pertunjukan Wayang Orang dapat menggunakan alur cerita maju atau mundur, hal tersebut sesuai keinginan sutradara dan dalang.

Pertunjukan Wayang Orang Njajah Desa Milang Kori lakon Gatotkaca Gandrung menggunakan alur cerita maju, yaitu menceritakan kisah dari awal munculnya sebab atau permasalahan kemudian konflik sebagai akibat dan penyelesaian. Bagian penyelesaian memiliki akhir cerita bahagia, yaitu Gatotkaca dapat bersatu dalam ikatan pernikahan dengan Pregiwa.

\section{Adegan}

Adegan merupakan bagian dari babak yang berhubungan dengan datang dan perginya tokoh cerita dalam pertunjukan. Adegan pada pertunjukan Wayang Orang dalam Njajah Desa Milang Kori tidak mengalami banyak perubahan dari pertunjukan Wayang Orang konvensional pada umumnya. Lakon Gatotkaca Gandrung terdiri dari sembilan adegan. Adegan pada pertunjukan Gatotkaca Gandrung sebagai berikut:

\section{Adegan Wana Krendhayana}

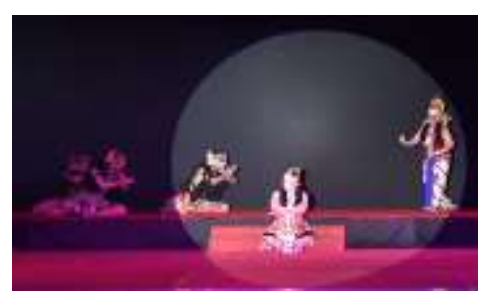

Foto 2. Adegan Wana Krendhayana

(Dok: video Gatotkaca Gandrung, 26 Januari 2019)

Adegan pertama yaitu bertempat di Wana Krendhayana yaitu di kediaman Lesmana, menggambarkan kegundahan Lesmana ingin mendapatkan Pregiwa. Lesmana melakukan semedi kemudian mendatangkan Bathari Durga bersama para pasukan Yaksa Cakil, prajurit putra dan prajurit putri untuk membantu Lesmana mewujudkan keinginanya.

\section{Adegan Kasatriyan Madukara}

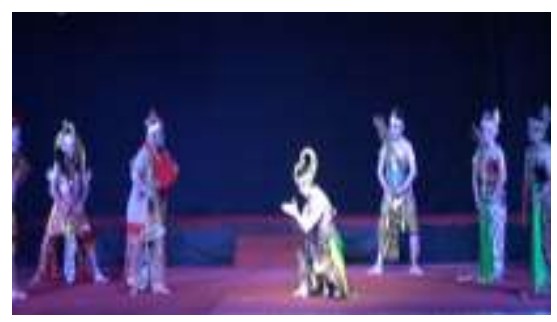

Foto 3. Adegan Kasatriyan Madukara (dokumentasi: video Gatotkaca Gandrung, 26 Januari 2019)

Adegan kedua bertempat di Madukara dengan suasana berbahagia, Arjuna dan para isteri sedang membincangkan pernikahan anaknya Pregiwa namun berubah gundah setelah kedatangan tamu Durna. Kedatangan Durna dan para Kurawa bermaksud untuk melamar Pregiwa. Kemudian Arjuna bingung, namun karena diancam kekuatan Arjuna akan dihilangkan 
kemudian Arjuna menyetujui pembatalan pernikahan Pregiwa dengan Gatotkaca. Arjuna mengutus Abimanyu untuk memberikan surat pembatalan pernikahan kepada Werkudara.

\section{Adegan Kasatriyan Jodhipati}

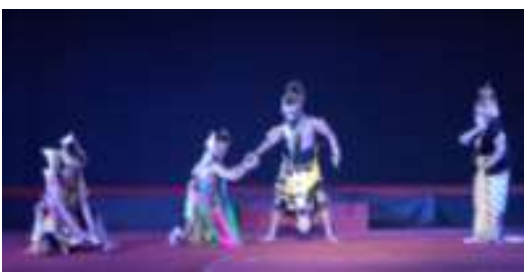

Foto 4. Adegan Kasatriyan Jodhipati (dokumentasi: video Gatotkaca Gandrung, 26 Januari 2019)

Adegan ketiga bertempat di Jodhipati yaitu kediaman Raden Werkudara dengan suasana bahagia karena akan menggelar pernikahan kemudian berubah suasana tegang dan marah. Raden Werkudara, Dewi Arimbi, dan Gatotkaca sedang membahas pernikahan Gatotkaca. Abimanyu datang memberikan secarik surat kepada Werkudara, ternyata isinya adalah pembatalan. Werkudara marah besar kemudian menghajar Gatotkaca, mengapa pernikahan bisa dibatalkan begitu saja.

\section{Adegan Madya Wana}

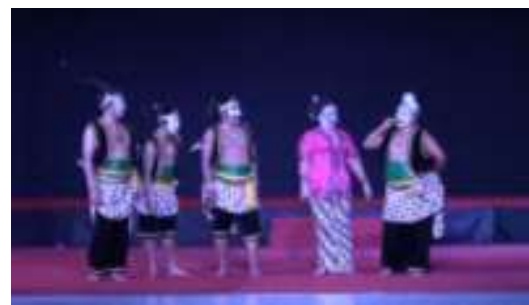

Foto 5. Adegan Madya Wana

(dokumentasi: video Gatotkaca Gandrung, 26 Januari 2019)

Adegan keempat bertempat di Madya Wana dengan suasana tenang dan mengandung humor untuk menghibur penonton. Muncul Goro-goro para Punokawan dan Nyai Kanastren yang sedang bersenang-senang. Adegan ini isinya adalah menyampaikan nasehatnasehat untuk masyarakat Desa Potronayan. Nasehat yang dimaksud adalah saling rukun, bergotong royong. Turut menyampaikan slogan Desa Potronayan yaitu "bersatu" yang memiliki kepanjangan Bersih Elok Rapi Sehat Aman Tertib dan Utuh".

\section{Adegan Candakan Madya Wana}

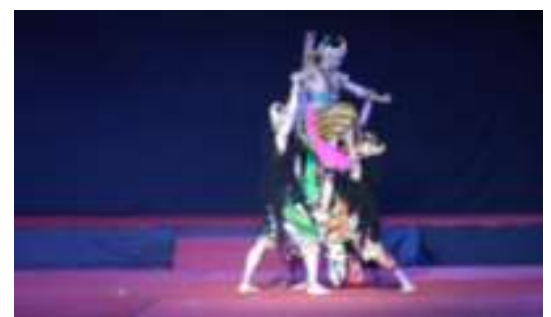

Foto 6. Adegan Candakan Madya Wana (dokumentasi: video Gatotkaca Gandrung, 26 Januari 2019)

Adegan kelima menggambarkan isian perjalanan Abimanyu dalam mencari kakaknya Gatotkaca yang diwujudkan dengan perang kembang. Perjalanan Abimanyu berangkat dari Kendayana, kemudian dihadang oleh para Yaksa Cakil kemudian terjadi peperangan yang biasa disebut perang kembang.

\section{Adegan Marga Imbangin Aldaka}

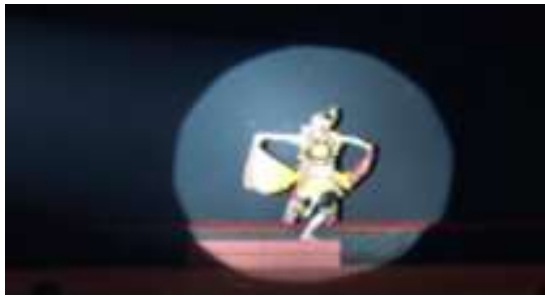

Foto 7. Adegan Candakan Madya Wana (dokumentasi: video Gatotkaca Gandrung, 26 Januari 2019)

Adegan keenam menggambarkan Gatotkaca sedang sedih, kecewa, putus asa dan ingin bunuh diri. Penggambaran kesedihan menggunakan ragam gerak abur-aburan. Namun setelah mendapat nasehat dari Kresna, ia bangkit kembali untuk mendapatkan Pregiwa.

Adegan Maduganda ing Kasatriyan Madukara

Adegan ketujuh bertempat di taman Madukara dengan suasana sedih. Pregiwa sedang bersedih hati karena pembatalan pernikahannya. Pregiwa 
ditemani oleh adiknya yaitu Pregiwati dan Limbuk, Cangik. Kemudian datang Gatotkaca membawa kabur Pregiwa.

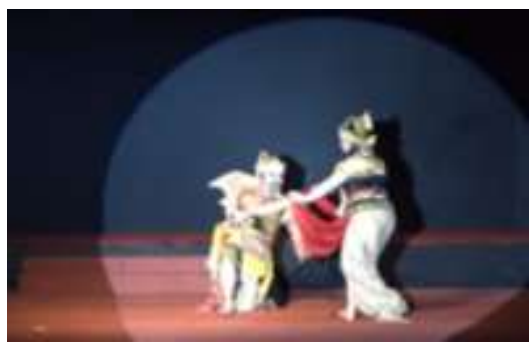

Foto 8. Adegan Madukara

(dokumentasi: video Gatotkaca Gandrung, 26 Januari 2019)

\section{Adegan Kasatriyan Madukara}

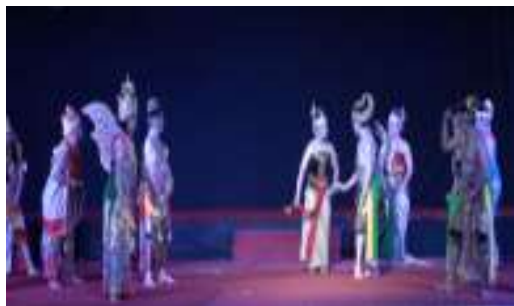

Foto 9. Adegan Kasatriyan Madukara

(dokumentasi: video Gatotkaca Gandrung, 26 Januari 2019)

Adegan kedelapan bertempat di Madukara dengan suasana tegang. Arjuna bersama para isteri menyambut kedatangan Prabu Puntadewa, Duryudana, dan para Kurawa. Mereka mengantarkan Lesmana dan diiringi oleh para prajurit. Ketika ditengah pembicaraan datang Pegiwati mengadu bahwa Pregiwa telah diculik oleh Gatotkaca. Mengetahui hal tersebut semua hanya bisa pasrah.

\section{Adegan Marga/Palagan}

Lesmana mengejar Pregiwa, namun ia kalah dalam perang dengan Gatotkaca. Kemudian sempat terjadi peperangan antara Arjuna dengan Werkudara, namun setelah dilakukan musyawarah akhirnya Arjuna merestui pernikahan Gatotkaca dengan Pregiwa.

\section{Dialog}

Dialog menjadi bagian yang vital dan perlu dilatih dalam pertunjukan Wayang Orang, karena penyampaian cerita Wayang Orang selain melalui gerak yaitu menggunakan dialog atau antawecana. Setiap tokoh Wayang Orang memiliki karakter nada dan pelafalan yang beranekaragam. Sehingga dalam pencapaian keberhasilan dialog harus menyesuaikan karakter tokoh masingmasing, yaitu melalui latihan.

Dialog yang digunakan dalam pertunjukan Wayang Orang menggunakan Bahasa Jawa Kawi, Bahasa Jawa Tengahan, Bahasa Rinengga dan Bahasa Ngoko. Dialog yang dibuat menyesuaikan peran pemain yang dibawakan, misalnya menggunakan dialog bahasa jawa ngoko halus biasa ketika melakukan dialog antara sesama tahta yaitu para raja kepada istrinya. Penggunaan bahasa jawa krama alus dan krama inggil biasa digunakan untuk dialog antar tokoh yang berusia muda kepada yang lebih tua, dan antar tokoh yang belum saling kenal dalam ceritanya.

Dialog dibuat dalam bentuk naskah, naskah tersebut dibuat oleh dalang dan sutradara. Dalang adalah Edi Sulistyono dan sutradara oleh Ali Marsudi. Proses membuat dialog yaitu semua tokoh Wayang Orang berkumpul dalam satu ruangan termasuk dalang dan sutradara, mereka saling melakukan dialog sesuai arahan dari narasumber yaitu dalang. Perbincangan dialog tersebut sambil direkam menggunakan handphone. Setelah direkam kemudian di transkip oleh dalang, dibagikan kembali ke pemain. Jadi, dialog dalam pertunjukan Wayang Orang Njajah Desa Milang Kori ada yang merupakan bagian dari naskah namun ada yang merupakan improvisasi pemain.

Gatotkaca : "Paman Arjuna, mboten ateges kula ndamel wirangipun tiyang asepuh. Sedaya ingkang kula tindakaken menika injih awit saking agengipun katresnan kula kaliyan yayi Pregiwa"

Arjuna : "Kuwi mung pawatan ngawur, ngawu gawar, anggonmu kepenging nalisir saka anggeranggering Kautaman, hayuh pedhotake katresnanmu kalawan Pregiwa apa ora Gatotkaca"

Gatotkaca : "Prayogi tinimbang kula kedah pedhotaken dedaupan katresnan kula dumateng yayi Pregiwa, aluwung tumekaning pejah Paman Arjuna" (Dokumentasi: 
Video Gatotkaca Gandrung, 26 Januari 2019)

Teks dialog di atas dapat diartikan dalam bahasa Indonesia yaitu sebagai berikut;

Gatotkaca : "Paman Arjuna, bukan maksud saya membuat malu orang tua. Semua ini saya lakukan karena rasa cinta saya terhadap Pregiwa"

Arjuna : "Itu hanya pijakan yang sangat ngawur sekali, perbuatanmu hanya ingin berbelok dari gerbang kebaikan dan keutamaan. Hayuh putuskan hubungan cintamu dengan Pregiwa atau tidak Gatotkaca?"

Gatotkaca : "Daripada saya harus memutuskan hubungan cinta saya dengan Pregiwa lebih baik saya mati Paman Arjuna"

\section{Garap Tari}

Pertunjukan Wayang Orang diperlukan adanya garap gerak tari dengan berbagai ragam bentuk. Garap gerak sebagai ungkapan estetis untuk menggambarkan suasana, tokoh, watak dan cerita yang disajikan. Gerak merupakan unsur penunjang yang paling besar peranannya dalam tari, Djelantik (2001:23). Gerak yang digunakan dalam pertunjukan Wayang Orang Njajah Desa Milang Kori lakon Gatotkaca Gandrung menggunakan ragam gerak tari gaya Surakarta. Berdasarkan peran lakon yang disajikan, gerak yang ditarikan para tokoh merupakan gerak dasar tari seperti lumaksana, srisig, jengkeng, sabetan, besut dan lain sebagainya.

Koreografer atau penata tari di Wayang Orang Njajah Desa Milang Kori adalah Wahyu Sapto, memiliki tugas pokok yaitu membantu sutradara menata gerak tari sesuai dengan konsep garap sutradara. Menata gerak termasuk mengolah garap gerak, menata posisi pola lantai penari, dan menata komposisi penari.

Wahyu Sapto menuturkan empat kendala dalam proses pertunjukan Wayang Orang Njajah Desa Milang Kori yaitu, kurangnya sumber daya manusia atau pemain dari RRI Surakarta, kurangnya pemahaman pemain terhadap kesesuaian gerak dengan iringan, kurangnya waktu latihan, dan adu argumen antara penata tari, sutradara, dalang, dan penata iringan. Meskipun kendala tersebut sering terjadi, namun ketika pertunjukan berlangsung dapat tersajikan dengan baik.

Sumber ide garap tari diperoleh melalui rangsang tuntutan konsep garap sutradara, rangsang audio yaitu ide yang diperoleh dari mendengarkan suara iringan, dan ide pengalaman menyaksikan wayang kulit.

\section{Tata Rias dan Busana}

Tata rias busana adalah keterampilan untuk mengubah, melengkapi atau membentuk sesuatu yang dipakai mulai rambut sampai ujung kaki, Lestari (1993:15). Tata busana yang digunakan dalam pertunjukan Wayang Orang Njajah Desa Milang Kori menggunakan kostum Wayang Orang yang lengkap. Tata busana merangkul kerjasama dengan Sanggar Griya Budaya Titah Nareswari. Sanggar Griya Budaya Titah Nareswari (GBTN) merupakan sanggar yang melingkupi bidang penyedia jasa persewaan dan pengadaan busana seni tradisional. Pemilik sekaligus pimpinan dari sanggar tersebut adalah Ali Marsudi. Sanggar tersebut beralamat di Sawah, Triyagan, Mojolaban, Sukoharjo, Jawa Tengah (57554).

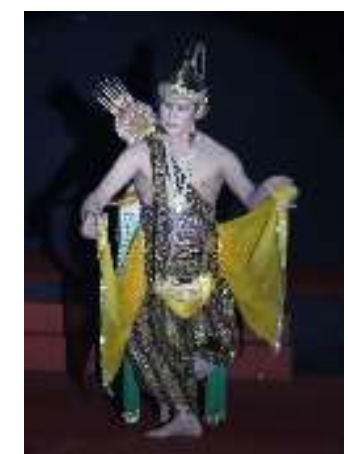

Foto 10. Tata busana tokoh Arjuna (Dokumentasi: Mita, 26 Januari 2019)

Contoh busana yang digunakan tokoh Arjuna menggunakan tata busana sebagai berikut; (1) Irah-irahan luruh adalah aksesoris mahkota yang digunakan di 
kepala berbentuk corong melengkung, terbuat dari kertas keras, kain bludru, payet dan kulit yang di prada emas. (2) Anak panah adalah peluru untuk memanah (3) Endong panah adalah tempat untuk menyimpan anak panah, terbuat dari kulit (4) Slempang adalah kain panjang yang digunakan menyilang mengalungi dada, untuk mengaitkan endong panah. (5) Keris adalah senjata yang terbuat dari kerangka kayu atau alumunium, isinya terbuat dari logam. (6) Sampur adalah kain berukuran 2-3meter x 0,5 meter dapat digunakan sebagai properti atau busana tari. (7) Bara Samir terdiri dari 3 bagian kain yang dipasang di pinggang kanan dan kiri. (8) Jarik lereng adalah kain berukuran 2,5meter x 1 meter dengan motif kain lereng. (9) Binggel kaki adalah gelang kaki (10) Sumping adalah aksesoris yang digunakan di telinga (11) Kalung tekak adalah kalung pendek digunakan di leher (12) Kalung ulur adalah kalung yang ukurannya lebih panjang dari kalung tekak, digunakan di leher. (13) Gelang tangan adalah aksesoris yang digunakan di pergelangan tangan (14) Stagen adalah kain panjang yang digunakan di pinggang dan perut bagian bawah. (15) Epek timang adalah sabuk dan gesper yang digunakan di pinggang. (16) Uncal adalah aksesoris untuk menutupi bagian depan kemaluan (17) Celana panji adalah celana berukuran $3 / 4$ yang terbuat dari bahan bludru dan dihiasi payet.

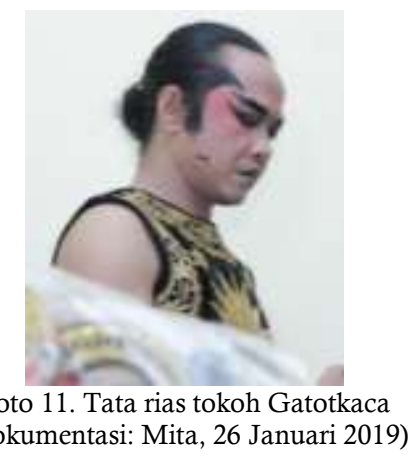

(Dokumentasi: Mita, 26 Januari 2019)
(Doto 11. Tata rias tokoh Gatotkaca

Foto diatas merupakan contoh rias karakter putra gagah thelengan, yaitu karakter yang disandang oleh tokoh Gatotkaca. Rias tokoh Gatotkaca menggunakan alis menjangan ranggah, laler menclok, sogokan, godeg, ujung mata dipanjangkan ke atas, dan jambang.

\section{Properti}

Properti adalah semua alat atau yang digunakan sebagai media atau perlengkapan dari pementasan tari, Jazuli (1994:107). Properti yang digunakan dalam pertunjukan Wayang Orang dalam Njajah Desa Milang Kori lakon Gatotkaca Gandrung adalah Cundrik yang digunakan oleh Prajurit Putri dan surat yang tujukan untuk Werkudara, sebagai berikut;

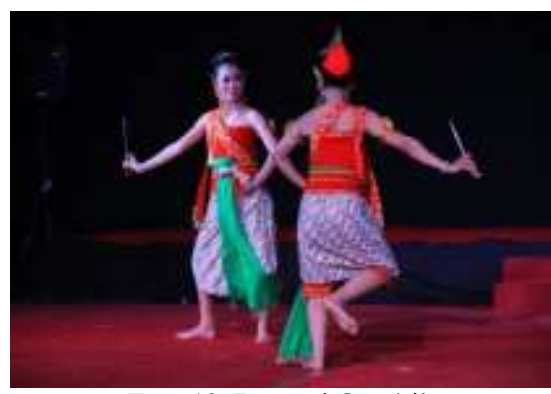

Foto 12. Properti Cundrik

(Dokumentasi: Mita, 26 Januari 2019)

Properti cundrik merupakan senjata yang digunakan oleh tokoh perempuan. Cundrik terdiri dari dua bagian yaitu badan cundrik dan warangka, badan cundrik yaitu bagian yang berbentuk panjang, memiliki ujung runcing, terbuat dari bahan logam putih, berukuran panjang kurang lebih $25 \mathrm{~cm}$ dan lebar $2 \mathrm{~cm}$. Bagian warangka yaitu terbuat dari kayu memanjang yang dilubangi tengahnya, lubang tersebut digunakan untuk menyimpan badan cundrik. Penggunaan properti Cundrik memiliki makna yang berbeda dalam penggunaanya, misalkan penggunaan cunrik pada adegan pertama yaitu menggambarkan kegigihan dan siap siaga dalam membantu mewujudkan keinginan Lesmana. Pada adegan ke-sembilan digunakan untuk menggambarkan peperangan dan gejolak hati Pregiwa divisualisasikan dengan tarian peperangan antara Prajurit Putri dan Pregiwa.

Properti surat mengandung makna bahwa Werkudara benar-benar menerima secarik surat dari Arjuna dan membaca pemberitahuan pembatalan pernikahan anaknya.

\section{Iringan}

Iringan adalah penghayatan isi hati manusia yang diungkapkan dalam 
bentuk bunyi yang teratur dengan melodi atau ritme serta mempunyai unsur atau keselarasan yang indah, Sunarko (1989:5). Iringan dalam pertunjukan Wayang Orang lakon Gatotkaca Gandrung menggunakan seperangkat gamelan laras pelog dan slendro.

Gamelan digunakan sebagai alat musik pengiring dari awal hingga selesai pertunjukan. Alat-alat gamelan yang digunakan antara lain kendang, saron 1, saron 2, kethuk, kenong, bonang 1, bonang 2 , kempul, gong, gender, peking dan rebab. Terdapat alat musik modern seperti saxophone dan drum set untuk memberikan pertanda atau penekanan saat adegan perang. Gamelan tersebut dimainkan oleh kelompok pengrawit dan sinden sebagai swarawati.

Berikut urutan iringan pada pertunjukan Wayang Orang Njajah Desa Milang Kori menggunakan; (1) vocal ilustrasi pada bagian prolog, menuju adegan satu menggunakan srepeg kemudian gangsaran dan vocal gangsaran, lancaran untuk mengiringi prajurit putri, di akhiri iringan rampogan. (2) Adegan dua menggunakan pathetan suluk pelog 5, ketawang Bosanta Pelog 5, Sendhon Banyumasan Slendro Manyura, Srepeg Lasem Slendro 6, Ayak-ayakan Lasem Slendro 6, Srepeg Mandras Slendro 6, Ayak Mangulis Slendro 6, Kemuda Slendro 6. (3) Adegan 3 menggunakan Ladrang Pisang Bali Slendro 9. (4) Adegan 4 menggunakan Ayak-ayakan Banyumas Slendro 9, Srepeg Banyumasan Slendro 9, Lelagon Glopa-Glape Slendro 9. (5) Adegan lima menggunakan Lancaran Garap, Vokal Lancaran, Sesegan Srepeg. (6) Adegan terakhir menggunakan Ayakayak Talu, Srepegan, Vokal Srepeg. Beberapa adegan menggunakan pengulangan iringan yang sudah ada.

\section{Tempat Pertunjukan}

Suatu pertunjukan tidak lepas dari tempat guna menyelenggarakan pertunjukan itu sendiri. Tempat atau ruangan tersebut disebut pentas, yaitu bagian dari arena pertunjukan yang ditata sedemikian rupa sebagai tempat bermain, Hadi (1987:43-44). Termpat pertunjukan Wayang Orang dalam Njajah Desa Milang Kori lakon Gatotkaca Gandrung dilaksanakan di Balai Desa Potronayan, Kecamatan Nogosari, Kabupaten Boyolali, Provinsi Jawa Tengah.

\section{Tata Panggung}

Tata panggung menggunakan tempat pendopo Balaidesa, sehingga penataan panggung dilakukan secara kondisional. Panggung yang digunakan dapat disebeut panggung nonkonvensional karena bereda dengan panggung khusus pertunjukan pada umumnya. Panggung non-konvensional memiliki ciri-ciri cenderung berubah-ubah bentuk dari pertunjukan satu dengan pertunjukan di tempat lain dan sederhana, dengan mengolah tempat seperti lapangan, pendopo, teras gedung atau kantor, balai ruang, dan lain sebagainya.

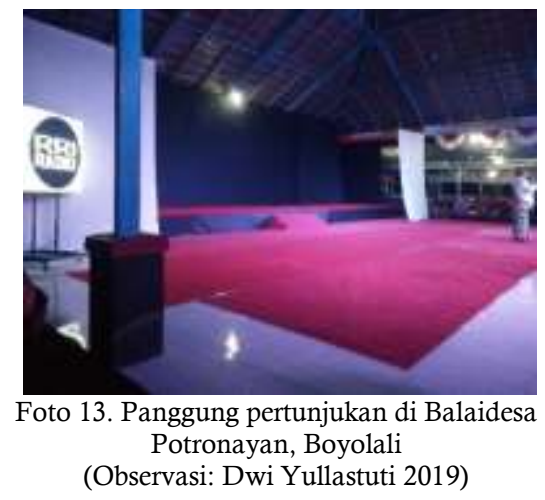

Bentuk panggung pada pertunjukan Wayang Orang Njajah Desa Milang Kori di Potronayan Boyolali seperti terdapat pada foto 15. Backdrop dibuat menggunakan kain hitam, ketinggian panggung menggunakan trap atau level dan dilapisi karpet merah. Pertunjukan di panggung non-konvensional tetap menggunakan fasilitas penunjang yaitu tata cahaya, tata suara, dan tata dekorasi.

Berikut adalah hasil wawancara langsung dengan Bapak Agus Marahendra Jaya sebagai operator lighting atau tata cahaya dari RRI Surakarta;

"Tata cahaya yang digunakan dalam pertunjukan Wayang Orang Njajah Desa Milang Kori mempercayakan persewaan dari luar mbak, kami tinggal memesan apa saja kebutuhannya dan bagaimana letak pemasangannya kemudian pihak persewaan menyiapkan dan menata lampu di lokasi, kami hanya tinggal 
mengoperatori di hari berlangsungnya acara saja mbak". (wawancara, 20 Maret 2019)

Berdasar wawancara, baik tata lampu dan tata suara menggunakan persewaan dari luar. Pemesanan dan persiapan dilakukan oleh pihak desa yang sanggup bekerjasama dengan Njajah Desa Milang Kori, spesifikasi telah ditentutkan oleh pihak Wayang Orang RRI Surakarta supaya pertunjukan dapat berjalan dengan lancar. Crew dari RRI Surakarta pada waktu pertunjukan hanya memberikan pengarahan saja, karena teknisi dilakukan oleh pihak persewaan.

\section{SIMPULAN}

Simpulan dari pembahasan Wayang Orang Njajah Desa Milang Kori RRI Surakarta dalam Lakon Gatotkaca Gandrung yaitu merupakan kegiatan yang langka, hanya LPP RRI Surakarta yang memiliki program pertunjukan Wayang Orang dengan konsep berpindah tempat atau berkeliling desa yang langsung terjun di masyarakat. Konsep pertunjukan ini tidak hanya memberikan tontonan namun juga memberikan tuntunan bagi masyarakat, upaya nyata mendekatkan Wayang Orang pada publik dalam arti yang luas. Masyarakat yang belum tahu wujud Wayang Orang supaya menjadi tahu, yang lupa menjadi ingat, dan yang ingat menjadi semakin akrab.

Konsep garap tetap menggunakan konsep garap konvensional yang berpijak pada pakem garap tradisional Wayang Orang. Sumber cerita dari kisah Ramayana dan Mahabarata, menggunakan peran dalang dan sutradara sebagai penyanggit dan pembawa cerita dan memiliki unsur pertunjukan yang konvensional.

Saran yang dapat penulis sampaikan untuk kelompok Wayang Orang LPP RRI Surakara yang menjalankan program Njajah Desa Milang Kori, yang pertama adalah agar semakin luas melakukan pertunjukan keliling Indonesia. Kedua, agar semakin semangat mempersembahkan lakon yang segar, menarik, memberi tuntunan baik, dan mengembangkan kualitas gerak para penari menjadi lebih baik.
Saran untuk masyarakat desa supaya ikut berpartisipasi dengan mengapresiasi pertunjukan Wayang Orang yang hampir punah ini, bagaimanapun tanpa adanya penonton maka sebuah pertunjukan adalah sia-sia. Harapannya agar dapat memunculkan seniman Wayang Orang baru dari desa-desa sebagai generasi pelestari budaya.

\section{DAFTAR PUSTAKA}

Djelantik, A. A. M. 2001. Estetika Sebuah Pengantar. Bandung: MSPI (Masyarakat Seni Pertunjukan Indonesia).

Fananie, Zainuddin. 2001. Telaah Sastra. Surakarta: Muhammadiyah University Press.

Harymawan, RMA. 1988. Dramaturgi. Bandung: Rosda.

Jazuli, M. 1994. Telaah Teoritis Seni Tari. Semarang: IKIP Semarang Press.

Kusharyani, M., Santoso, B., \& Wisnaeni, F. Eksistensi Dan Perlindungan Wayang Orang Sriwedari Surakarta Ditinjau Dari Aspek Hukum Hak Cipta. Law Reform, 12(1), 60-72.

Lestari, Wahyu. 1993. Teknologi Rias Panggung. Hand Out: IKIP Semarang Press.

Singarimbun, Masri dan Sofian Effendi. 1989. Metode Penelitian Survai. Jakarta: PT Pustaka LP3ES.

Soedjadi. 2000. Kiat Pendidikan Matematika di Indonesia. Bandung: Dirjen Dikti. Depdiknas.

Sulanjari, Dwi Retno. 2016. Regenerasi Penari Wayang Orang Sriwedari. Yogyakarta: UNY.

Sunarko, Hadi. 1989. Seni Musik I. Klaten: PT. Intan Pariwara. 